\title{
Pelatihan Cara Menggunakan Situs Bimbingan Belajar Free Bagi Pelajar dengan Memanfaatkan Website Zenius.Net
}

\author{
Baiq Rina Amalia Safitri ${ }^{1}$, Baiq Azmi Sukroyanti ${ }^{2}$, Lovy Herayanti ${ }^{3}$, Saiful Prayogi ${ }^{4}$, \\ Wirawan Putrayadi ${ }^{5}$, Pahriah ${ }^{6}$ \\ ${ }^{1}$ Prodi Pendidikan Teknologi Informasi, FSTT, UNDIKMA, Jl. Pemuda No. 59A, Mataram, \\ Indonesia 83125 \\ ${ }^{23456}$ Prodi Pendidikan Fisika, FSTT, UNDIKMA, Jl. Pemuda No. 59A, Mataram, Indonesia 83125 \\ laluimam44@gmail.com/081907330939
}

\begin{abstract}
Abstrak. Tujuan pengabdian ini adalah meminimalkan dampak negatif internet. Metode pelaksanaan pengabdian, antara lain: (1) Persiapan kegiatan; 1) Mekanisme pelaksanaan kegiatan, sebelum terjun ke lapangan, maka perlu dilakukan beberapa hal sebagai bentuk persiapan, antara lain: (a) Melakukan pendataan dan verifikasi pelajar di desa Sukamulia. (b) Sosialisasi program kepada pelajar di desa Sukamulia terkait rencana program pengabdian dan karakteristik pelajar setempat yang akan dilibatkan dalam pelaksanaan program kerja. 2) Materi pengabdian, materi yang akan disampaikan kepada pelajar dalam pelatihan pembuatan akun dan cara menggunakan situs bimbingan belajar free antara lain: (a) Menyiapkan materi untuk pembuatan membuat akun zenius.net, (b) Menyiapkan materi cara menggunakan zenius.net. (2) Pelaksanaan pelatihan; pelatihan dilakanakan terhadap para pelajar yang ada di desa Sukamulia, menggunakan metode Direct Instruction. Hasil yang ingin dicapai dari kegiatan atau program Pengabdian ini adalah sebesar-besarnya untuk kepentingan para pelajar setempat sebagai berikut: (1) Akun situs bimbingan belajar dan menciptakan belajar mandiri para pelajar dengan memanfaatkan situs bimbingan belajar tidak berbayar untuk mengurangi dampak negatif internet dan meningkatkan motivasi serta meningkatkan prestasi belajar para pelajar. (2) Publikasi artikel dalam jurnal. Kesimpulannya dengan memanfaatkan Website Zenius.Net" yaitu diharapkan dapat memberikan teknologi dan keterampilan kepada para pelajar bagaimana cara membuat akun dan cara menggunakan situs bimbingan belajar Free, sehingga dapat mengurangi dampak negatif internet.
\end{abstract}

Kata Kunci: Bimbingan Belajar, Zenius, Net

\section{PENDAHULUAN}

Menurut UU No.20 tahun 2003 Pendidikan adalah usaha dasar dan terencana untuk mewujudkan suasana belajar dan proses pembelajaran agar peserta didik secara aktif mengembangkan potensi dirinya untuk memiliki kekuatan spiritual keagamaan, pengendalian diri, kepribadian, kecerdasan, akhlak mulia, serta keterampilan, yang diperlukan dirinya, masyarakat, dan Negara.

Menurut Yunus dalam (Seputar pengetahuan, 2015) menyatakan bahwa pendidikan ialah suatu usaha yang dengan sengaja dipilih untuk mempengaruhi dan membantu anak yang bertujuan untuk (Widomoko, 2005) meningkatkan ilmu pengetahuan, jasmani dan akhlak sehingga secara perlahan bisa mengantarkan anak tujuan dan cita-citanya yang paling tinggi. Agar memperoleh kehidupan yang bahagia dan apa yang dilakukan dapat bermanfaat bagi dirinya sendiri, masyarakat, bangsa, negara dan agamanya.

Pendidikan merupakan suatu cara pembentukan manusia untuk belajar menggunakan rasionya seefektif dan seefisien mungkin untuk menjawab berbagai masalah yang timbul dalam usaha menciptakan masa depan yang lebih baik seiring dengan kemajuan teknologi dan perkembangan zaman. Hal ini akan dicapai apabila proses belajar mengajar dieselenggarakan secara professional serta kurikulum yang disajikan telah sesuai dengan perkembangan dan kebutuhan masyarakat. Jadi pendidikan harus didesain untuk memberikan pemahaman terhadap peserta didik sehingga meningkatkan kualitas belajar mereka.

Strategi yaitu suatu garis-garis besar haluan untuk bertindak dalam usaha mencapai 
sasaran yang telah ditentukan. Sehubungan dengan belajar mengajar, strategi bisa diartikan sebagai pola-pola umum kegiatan guru anak didik dalam perwujudan kegiatan belajar mengajar untuk mencapai yang telah ditentukan (Fathurrohman dan Sutikno, 2007).

Pada umumnya pembelajaran memiliki kendala karena masih menggunakan pembelajaran konvensional dan tidak menggunakan media pembelajaran. Fasilitas multimedia dapat membuat belajar lebih menarik, visual dan interaktif. Hamalik dalam (Arsyad, 2011) menyatakan bahwa pemakaian media pembelajaran dalam proses pembelajaran dapat membangkitkan motivasi dan rangsangan kegiatan belajar, dan bahkan membawa pengaruh-pengaruh psikologi terhadap siswa.

Hasil penelitian berjudul "Keamanan Penggunaan Media Digital pada Anak dan Remaja di Indonesia" yang yang dilakukan lembaga PBB untuk anak-anak, UNICEF, bersama para mitra, termasuk Kementerian Komunikasi dan Informatika dan Universitas Harvard, AS. Studi ini menelusuri aktivitas online dari sampel anak dan remaja yang melibatkan 400 responden berusia 10 sampai 19 tahun di seluruh Indonesia dan mewakili wilayah perkotaan dan pedesaan. Sebanyak 98 persen dari anak dan remaja mengaku tahu tentang internet dan 79,5 persen di antaranya adalah pengguna internet (Panji, 2014).

Menteri Pendidikan dan Kebudayaan (Mendikbud) Nadiem Anwar Makarim menerbitkan Surat Edaran Nomor 4 Tahun 2020 tentang Pelaksanaan Pendidikan Dalam Masa Darurat Coronavirus Disease (Covid19). Salah satu pokok penting dalam edaran ini adalah keputusan pembatalan ujian nasional (UN) Tahun 2020. Mendikbud menekankan bahwa pembelajaran dalam jaringan (daring)/jarak jauh dilaksanakan untuk memberikan pengalaman belajar yang bermakna bagi siswa, tanpa terbebani tuntutan menuntaskan seluruh capaian kurikulum untuk kenaikan kelas maupun kelulusan.

Sejak Pandemi virus corona terjadi, pembelajaran dilakukan di rumah dengan pembelajaran daring sesuai dengan keputusan Menteri Pendidikan dan Kebudayaan. Oleh karena itu, para pelajar memiliki kesempatan belajar di rumah dengan kuota internat lebih banyak, namun, para pelajar memanfaatkannya untuk main games, media sosial, menonton yang menghibur, dan lainlain. Hal ini tidak dimanfaatkan secara maksimal oleh para pelajar, dimana seharusnya memanfaatkan untuk hal-hal positif seperti menonton video pembelajaran, ikut bimbingan belajar gratis melalui websitewebsite gratis seperti zenius.net.

Rahmayati dan Handayani (2013) menyatakan analisis terhadap fasilitas yang digunakan oleh responden dari internet mayoritas responden menggunan www (World Web Wide), email dan chatting dengan tingkat paling sering yang digunakan mayoritas adalah www. World Web Wide adalah fasilitas yang paling banyak digunakan oleh pengguna internet di Indonesia. Penelitian Nasution (2006) juga menyatakan hal yang sama dan juga survey oleh Mahani (2007). Ada banyak fasilitas dalam internet yang dapat digunakan tetapi www adalah fasilitas yang banyak dikenal dan umumnya digunakan.

(Hutapea, 2019) menyatakan Website Zenius.net sebagai situs untuk belajar bagi siswa secara daring (online). Zenius menghadirkan materi belajar berkualitas, lengkap, praktis, dan terjangkau. Lengkap maksudnya tersedia materi pelajaran dari kelas 1 SD sampai 12 SMA sesuai kurikulum KTSP, Kurikulum 2013, dan Kurikulum 2013 Revisi. Selain itu, ada materi dan soal ujian sekolah, ujian nasional, dan seleksi masuk perguruan tinggi. Tujuannya, membuat materi belajar dan pengajaran menjadi lebih dekat dan mudah diakses pelajar.

Salah satu cara meminimalkan dampak negatif internet bagi para pelajar dan sekaligus untuk meningkatkan minat belajar para pelajar yaitu dengan mengenalkan situssitus belajar yang menyenangkan dan menanamkan konsep dalam belajar sehingga para pelajar mudah mengerti dan otomatis dapat meningkatkan prestasi belajar para pelajar.

Untuk mengatasi permasalahan di atas, maka perlu dilakukan pelatihan bimbingan belajar bagi para pelajar di Desa Sukamulia. 
Sehingga, penyaji mengambil judul "Pelatihan Cara Menggunakan Situs Bimbingan Belajar Free Bagi Pelajar dengan Memanfaatkan Webite Zenius.Net".

\section{METODE PENELITIAN \\ Persiapan dan Pelatihan \\ Persiapan Kegiatan}

Mekanisme pelaksanaan kegiatan

Sebelum terjun ke lapangan, maka perlu dilakukan beberapa hal sebagai bentuk persiapan, antara lain: (a) Melakukan pendataan dan verifikasi pelajar atau survey lokai di Desa Sukamulia. (b) Sosialisasi program kepada pelajar di Lingkungan Desa Sukamulia terkait rencana program pengabdian dan karakteristik pelajar setempat yang akan dilibatkan dalam pelaksanaan program kerja.

\section{Materi pengabdian}

Materi yang akan disampaikan kepada pelajar dalam pelatihan Membuat Akun dan Cara Menggunakan Situs Bimbingan Belajar Free antara lain: (a) Menyiapkan materi untuk pembuatan membuat akun Zenius.net. (b) Menyiapkan materi cara menggunakan Zenius.net

\section{Pelaksanaan Pelatihan}

Pelatihan dilakanakan terhadap pelajar yang ada di Desa Sukamulia, menggunakan metode Direct Instruction. Dimana, (Sakti, 2012) menggunakan Direct Instruction adalah model yang dirancang untuk meningkatkan penguasaan berbagai keterampilan (pengetahuan prosedural) dan pengetahuan faktual yang dapat diajarkan secara langkah demi langkah (Prayogi dalam Nurhaerani 2015).

Model Direct Instruction dalam penelitian ini adalah model pembelajaran yang yang dirancang khusus untuk mengembangkan belajar siswa tentang pengetahuan prosedural dan pengetahuan deklaratif yang terstruktur dengan baik dan dapat dipelajari selangkah demi selangkah.

Kelebihan Model Direct Instruction antara lain: (a) Penyaji bisa mengontrol urutan dan keluasan materi pelajaran, dengan demikian guru dapat mengetahui sampai sejauh mana peserta menguasai bahan pelajaran yang disampaikan. (b) Efektif bila materi pelajaran yang harus dikuasai peserta cukup luas, sementara itu waktu yang dimiliki untuk belajar terbatas. (c) Selain peserta dapat mendengar melalui penuturan tentang sesuatu materi pelajaran, juga sekalius peserta bisa melihat atau mengobservasi melalui pelaksanaan demonstrasi. (d) Bisa digunakan untuk jumlah peserta dan ukuran kelas yang besar.

\section{HASIL DAN PEMBAHASAN}

Pelatihan ini dilaksanakan pada tanggal 8 Juni 2020 sampai 16 Juni 2020 pada pelajar di Desa Sukamulia. Bentuk kegiatan dalam pelatihan ini adalah pelatihan membuat akun dan cara menggunakan situs bimbingan belajar free. Manfaat dari pelatihan ini adalah sebagai berikut: memiliki akun sendiri dan dapat digunakan setiap saat untuk memperoleh bimbingan belajar secara gratis. Peserta dalam kegiatan ini adalah para pelajar di Desa Sukamulia. Fasilitator dalam kegiatan ini adalah dosen UNDIKMA yang mengajar di Fakultas Sains, Teknik dan Terapan.

Seluruh peserta diharapkan akan mendapatkan materi dalam 2 (dua) kategori yaitu materi yang akan disampaikan kepada para pelajar dalam pelatihan situs bimbingan belajar free antara lain: a) pelatihan membuat akun situs bimbingan belajar free. b) pelatihan cara menggunakan situs bimbingan belajar free.

Metode yang digunakan dalam pelatihan yakni metode Direct Instruction. Dimana, Direct Instruction adalah yaitu model yang dirancang untuk meningkatkan penguasaan berbagai keterampilan (pengetahuan prosedural) dan pengetahuan faktual yang dapat diajarkan secara langkah demi langkah.

Pertama-tama membagikan materi berupa hard copy tentang membuat akun dan cara menggunakan situs bimbingan belajar free kepada para peserta pelatihan. Penyampaian materi pelatihan menggunakan Laptop dan LCD, supaya para peserta dapat melihat langsung sehingga para peserta dapat memperaktikkan langsung serta dapat menanyakan secara langsung apabila ada kesulitan. 
Contoh akun pembelajaran free yang dimiliki peserta adalah:

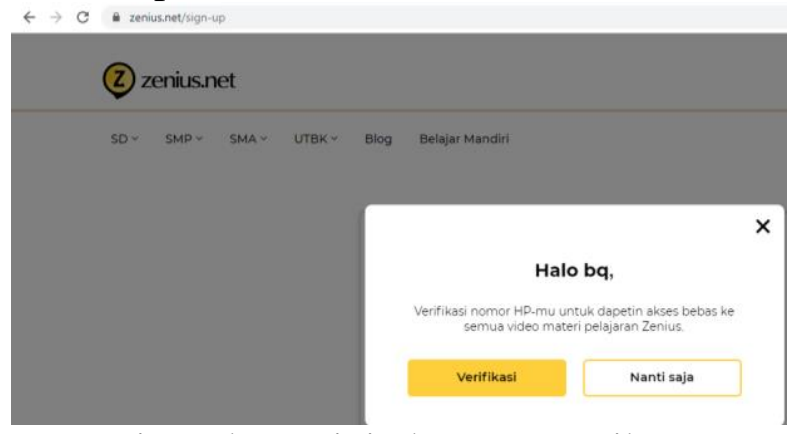

BimBel Free ini..dengan tampilan Menu seperti di bawah ini.

\section{Ada SD}

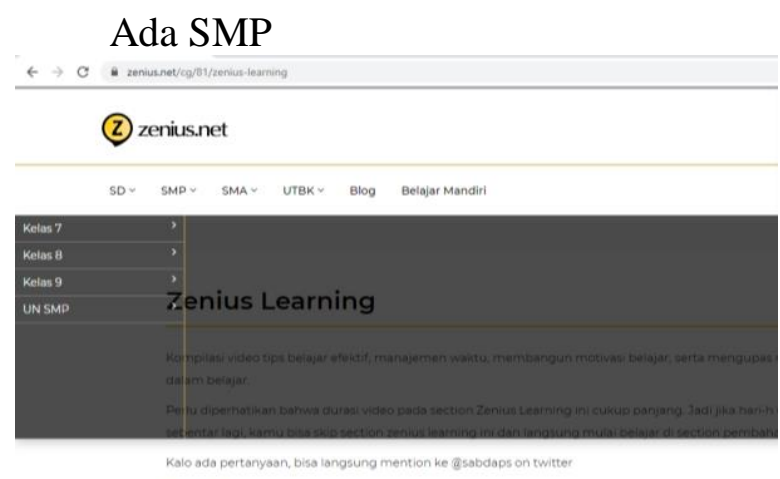

Ada SMA

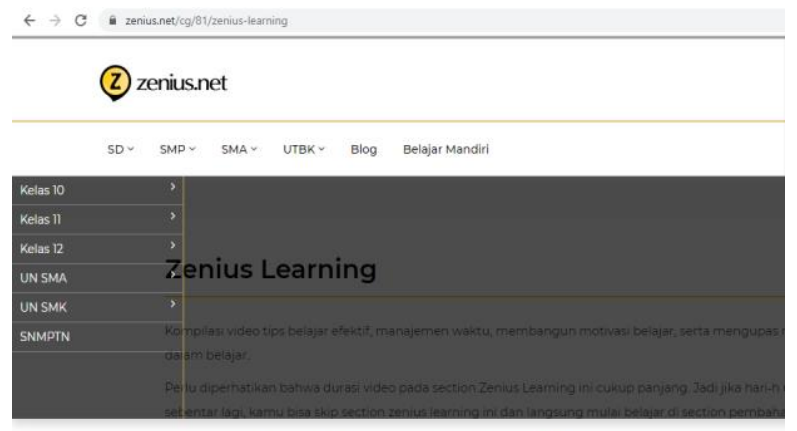

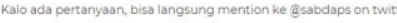

\section{Ada UTBK}

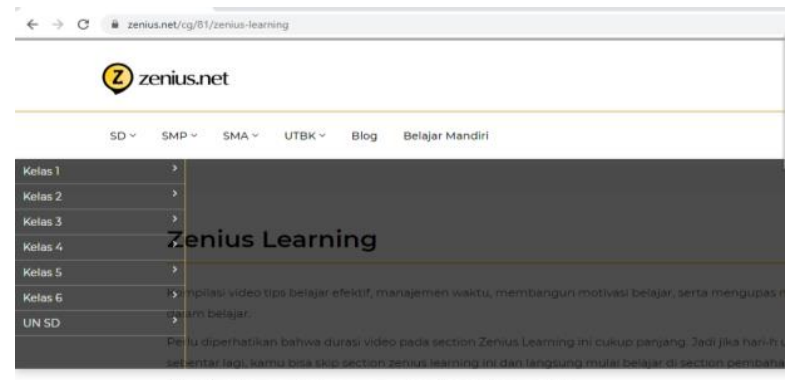

Kalo ada I

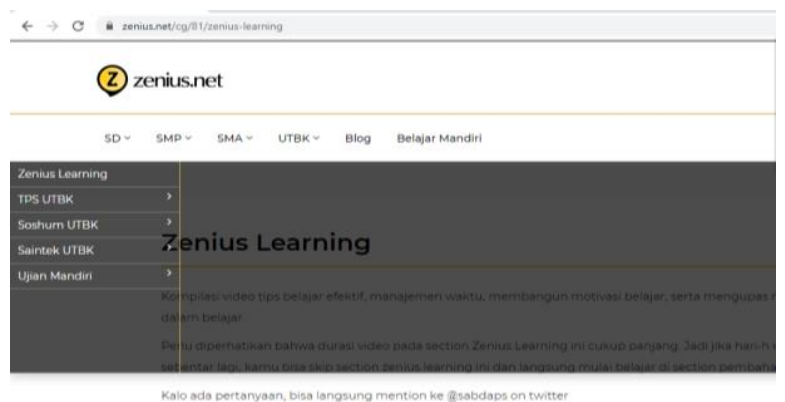

Kaio ada pertorng

Seperti Video Konsep di bawah ini.

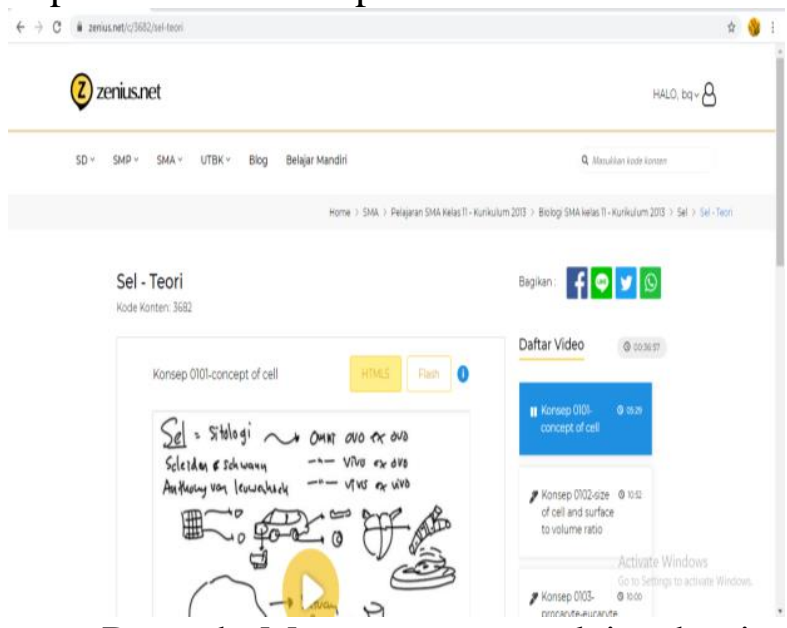

Dan ada Menu-menu yang lain, dan itu bisa diakses begitu mudah.

Alhamdulillah selama pelatihan berlangsung, para peserta sangat semangat dan antusias, dilihat dari semua peserta memiliki handphone dan sebagian mempunyai laptop serta langsung mempraktekkannya. Bila ada yang kurang jelas dari awal materi, para peserta sangat aktif dan tidak sungkan-sungkan untuk bertanya dan saling membantu.

\section{KESIMPULAN}

Target dari Program Pengabdian "Pelatihan Membuat Akun dan Cara Menggunakan Situs Bimbingan Belajar Free Bagi Pelajar di Desa Sukamulia dengan Memanfaatkan Website Zenius.Net" yaitu diharapkan dapat memberikan teknologi dan keterampilan kepada para pelajar bagaimana cara membuat akun dan cara menggunakan situs bimbingan belajar Free.

Hal ini juga memberi manfaat meminimalkan dampak negatif internet bagi para pelajar dan sekaligus untuk meningkatkan minat belajar para pelajar yaitu dengan mengenalkan situs-situs belajar yang menyenangkan dan menanamkan konsep dalam belajar sehingga para pelajar mudah 
mengerti dan otomatis dapat meningkatkan prestasi belajar para pelajar.

\section{SARAN}

Selain memanfaatkan Website Zenius.Net untuk belajar, para pelajar juga dapat memanfaatkan situs-situs bimbingan belajar gratis lainnya. Hambatan yang harus dihindari saat pengabdian yaitu kurangnya dapat sinyal internet sehingga dapat menghambat pembelajaran.

\section{UCAPAN TERIMA KASIH}

Ucapan terima kasih kepada yayasan pembina IKIP Mataram atas support dananya.

\section{DAFTAR PUSTAKA}

Arsyad. 2011. Media Pengajaran. Jakarta: Raja Grafindo Persada.

Biro Komunikasi dan Layanan Masyarakat Kementerian Pendidikan dan Kebudayaan. Jakarta, 24 Maret 2020. Mendikbud Terbitkan SE tentang Pelaksanaan Pendidikan dalam Masa Darurat Covid-19. (Diakses 1 April 2020 Laman: www.kemdikbud.go.id)

Fathurrohman, Pupuh dan Sutikno, M., Sobry. 2007. Strategi Belajar Mengajar Melalui Penanaman Konsep Umum dan Konsep Islam. Jakarta: Refika Aditama.

Hutapea, E. 2019, Juli 17. Pengalaman Belajar Belum Menyenangkan, Zenius Rilis Aplikasi

"Mobile". (Retrieved Februari 11, 2020, from

KOMPAS.COM:https://edukasi.ko mpas.com $/ \mathrm{read} / 2019 / 07 / 17 / 21050$ 881/pengalaman-belajar-belummenyenangkan-zenius-rilisaplikasimobile?page $=$ all).

Nurhaerani, 2015.Pengaruh Model Direct Direct Instruction Berbasi Multimedia PhET terhadap Motivasi Belajar dan Pemahaman Konsep Fisika Siswa Skripsi. IKIP Mataram.

Melani, Cita. 2008. Motif dan Pola penggunaan media internet oleh mahasiswaAbstrak. Fikom Library and Knowledge Center.

Panji, Aditya. 2014. Hasil Survei Pemakaian Internet Remaja Indonesia.
(Diakses $1 \quad$ April

2020 https://tekno.kompas.com/re ad/2014/02/19/1623250/Hasil.Sur vei.Pemakaian.Internet.Remaja.In donesia.)

Rahmayati, El dan Handayani, Ririn, Sri. April 2013. Analisis Pola Penggunaan dan Pemanfaatan Internet Oleh Mahasiswa di Lingkungan Politeknik Kesehatan Tanjungkarang. Jurnal Keperawatan, Volume IX, No. 1, ISSN 1907-0357.

Surat Edaran Nomor 4 Tahun 2020 Tentang Pelaksanaan Kebijakan dalam Masa Darurat Peyebaran Corona Virus Disease (COVID-19).

Sakti Dkk. 2012. Pengaruh model pembalajaran langsung (direct instruction) Melalui media animasi berbasis macromedia flash terhadap Minat belajar dan pemahaman konsep fisika siswa di SMA plus Negeri 7 kota Bengkulu. Jurnal Exacta, ISSN 1412-3617.

Seputar Pengetahuan. 2015. 40 Pengertian Pendidikan Menurut Para Ahli (Pembahasan Lengkap). (Retrieved 3 1, 2019, from 40 Pengertian Pendidikan Menurut Para Ahli (Pembahasan Lengkap): http://www.seputarpengetahuan.co .id/2015/2015-pengertianpendidikan-menurut-paraahli.html).

Undang-undang Republik Indonesia Nomor 20 Tahun 2003 Tentang Sistem Pendidikan Nasional.

Widomoko. (2005). Kontruksi Bangunan Gedung Satu Lantai. Malang: Universitas Negeri Malang. 